\title{
Initiation of the Consortium by US Secretary of Defense William Cohen during an intervention at the meeting of the Euro - Atlantic Partnership Council Defence Ministers (EAPC-D) in Brussels, Belgium, on June 12, 1998.
}

\author{
Secretary of Defense William Cohen's Remarks on PFP in the EAPC/D \\ on June 12, 1998
}

\section{Vision of PFP in the 21st Century}

Our ultimate goal for the 21st century should be a cooperative security network of Allies and Partners, with PFP as the cornerstone. Therefore, we must remain steadfast in our commitment to PFP's evolution as an independent framework for European security, worthy of membership in its own right, as well as its preparatory role for Alliance membership for those who desire it. While PFP will remain a primary vehicle for preparing aspiring NATO members for the military obligations that Alliance membership entails, it is not just a stepping stone and should not be portrayed simply in these terms. In other words, PFP is not a means to an end. It is an end in itself. As we continue the process begun in 1991 of recognizing that new challenges mean new missions for the Alliance, we should always look for opportunities for Partner participation in those missions. Thus the increasing role of Partners should be reflected in the updated Strategic Concept.

\section{Continue Enhancements}

We've already taken a major step toward creating this 21st Century cooperative security network of Allies and Partners by agreeing to and implementing PFP enhancements. A year ago at Madrid, our governments agreed to a substantial package of enhancements that, when fully implemented, will create a fundamentally different Partnership - one in which Partners have a greater voice in the management of PFP and numerous new opportunities to build interoperability with NATO and learn NATO procedures. In the Consolidated Report on PFP Enhancement, we said we would give Partners a greater voice in PFP affairs and regularize Alliance consultations with them. We've since established the EAPC, and it had a successful first year: More than a dozen EAPC bodies met at levels ranging from ministers and ambassadors to subject experts. A week does not go by at NATO without some type of EAPC discussion. For example, EAPC ambassadors and military representatives meet monthly, the EAPC Political-Military Steering Committee meets twice a week and the EAPC in SFOR format meets once a week. In the same report, we said we would create PFP Staff Elements (PSEs). We've now chosen the 38 Partner officers to fill the eight PSEs that will be up and running in just a matter of weeks. We promised to open to Partners permanent military posts in the Partnership Coordination Cell (PCC). Seven Partner officers are now serving in those PCC posts, including one in a leadership position in which 
Allied and Partner officers alike report to him. We pledged to make the Planning and Review Process (PARP) more like NATO's defense planning process. With today's endorsement of the report on expanding and adapting the PARP, we'll have a more operationally-focused PARP nearly indistinguishable from NATO defense planning, complete with Ministerial Guidance and its own version of force goals. We agreed to allow Partners to open full-fledged Missions to NATO; 26 of 27 PFP partners have either done so or have announced their intention to do so. We sought to expand the scope of NATO infrastructure funding to PFP projects. We now have agreement on the first two projects. These projects will allow for ease of communications in Partner staff elements and better connectivity between PSEs and Partner capitals. Finally, we agreed to open up the range of NATO's senior committees to partner participation. Partners are now well integrated into nearly all of NATO's committees and are making daily contributions in diverse areas such as armaments cooperation, airspace management, and civil emergency planning. Of course, the job is not complete. For example, we've only begun to tackle the remit to create a Political-Military Framework for NATO-led PFP operations. Allies and Partners should continue our work toward fulfilling these PFP enhancements so that we may complete the task of PFP enhancement by the April 1999 Washington Summit.

\section{Taking PFP to the Next Level}

As we begin to focus on next year's Summit, we need to start now to develop initiatives to make PFP even more visible and central to the Summit. The United States encourages all Allies and Partners to make proposals for doing so. Today, let me outline U.S. thoughts on improving the PFP training and education system. There is no doubt that PFP exercises-especially as they have been made more complex and qualitative over the past year-provide valuable training to partners. However, we believe there is further room for improvement, with more focused training geared to specific operational and security objectives. For example, there is currently no regular system of feedback on Partner performance in exercises. Specifically, PFP needs to refine its education and training to better incorporate the lessons learned from the wide scope of exercises and other activities that we're carrying out. We need a framework for assessment and measurement of Partner performance against specific standards. Also, we need a way to help Partners tailor their PFP participation to achieve specific interoperability objectives. Widespread interest among Partners to establish their own PFP training centers underscores that PFP is ready to move to the next phase. Partners and Allies alike recognize the need to graduate to higher levels of sophistication in the conduct of military exercises, as well as securing meaningful feedback from participation in these exercises. Within the scope of PFP, both Allies and Partners need to concentrate energy and resources, while collecting and sharing lessons learned. One way to accomplish this is to strengthen existing defense educational institutions by linking them together. The United States has a three-part proposal for building among nations this enhanced education and training framework: 1. A Consortium of Defense Academies and Security Studies Institutes; 2. An exercise simulation network focused on 
peace support operation scenarios; and 3. A cooperative network of nationally-sponsored PFP training centers. These proposals are mutually reinforcing and designed to facilitate the evolution of PFP into a robust security institution.

\section{PFP Consortium of Defense Academies and Security Studies Institutes}

The goal of the proposed "Partnership for Peace Consortium of Defense Academies and Security Studies Institutes"-sponsored jointly by the United States and Germany-is to strengthen defense and military education through enhanced national, institutional cooperation. As cosponsors, the U.S. and Germany hope to increase the number of individuals in Government and private sectors with defense and security policy expertise, further promote professional military education in participating nations, and encourage collaborative approaches to defense education. In addition to our Governmental Defense Academic Institutions and Security Studies Institutes, we believe non-governmental institutes, universities and other similar bodies will also have a valuable potential part to play in this work. All of these bodies can participate in the projected activities of the Consortium, which include:

- an annual conference, which would provide the venue for expert level planning workshops for the activities of ad hoc groups which would be "commissioned" during the conference;

- these ad hoc groups would meet at expert level more frequently and provide for more effective exchanges of information and ideas on PFP-related topics such as training and education.

- a scholarly journal as a mechanism to promote and stimulate leading ideas, with distribution to participants and interested parties' libraries and colleges.

- a Consortium world wide web home page for sharing information.

The Consortium will be a cooperative arrangement of national institutions in the spirit of PFP. It will be for the participating countries to fully define and develop both the scope for the Consortium and how it will operate. To help get started, I and my colleague from the Federal Republic of Germany, Minister Volker Ruehe, are offering the Marshall Center to serve as the interim secretariat for the Consortium, until longerterm arrangements are determined by Consortium. Several Ministers in our group have expressed a willingness to support the Consortium by hosting conferences and providing supporting staff. I look forward to hearing their remarks about this initiative and how best to get started.

\section{PFP Simulation Network for Peace Support Operations}

In an era of increased operational deployments and diminishing resources, all military forces must take advantage of more cost-effective training resources. Simulation is such a resource. We have seen computer simulations used to great effect as part of the second Combined Joint Task Force implementation trial. SACEUR and SACLANT cooperation in the implementation of two recent NATO exercises with Partner partici- 
pation provides a model for the future. SACLANT's exercise, Unified Endeavor, prepared commanders and staffs from Allied and Partner countries for successful participation in the follow-on CJTF field trial, Strong Resolve. Unified Endeavor demonstrated the importance of computer simulation in helping to collect and share lessons learned, provide feedback, and measure performance against stated objectives. We are examining proposals to expand on this success through distributed training employing satellite and computer technology. We hope to bring forward our proposals for wider consideration at December's Ministerial meetings.

\section{Looking to the Future: PFP Training Centers}

I welcome the many proposals that Partners have made for PFP training centers -- from Romania, the Former Yugoslav Republic of Macedonia, Sweden, and Ukraine. This represents a strong willingness by more Partners to become more closely integrated into NATO's day-to-day work. These centers, however, should not be billed as "regional" centers. Partners and Allies from all areas should plan to use them, not just those closest geographically. Instead, these centers should be "functional" centers, each with a specialization in a particular training area. For example, one center could focus on training for peace support operations, another on defense resource management, while yet another could be dedicated to maneuver and field exercise training. I propose that the Alliance close on the issue of which of these proposals to designate as "PFP training centers" by the time of the next Ministerial in December, with a goal of having these centers open and functioning by the time of the April 1999 summit. This will give concrete substance to what the U.S. hopes will truly be a Partner Summit. 